\title{
Levels of nitric oxide metabolites, adiponectin and endothelin are associated with SNPs of the adiponectin and endothelin genes
}

\author{
NADEZHDA G. GUMANOVA ${ }^{1}$, MARINA V. KLIMUSHINA ${ }^{1}$, STEPAN A. SMETNEV ${ }^{1}$, \\ ANNA V. KISELEVA ${ }^{1}$, OLGA P. SKIRKO ${ }^{1}$, ALEXEY N. MESHKOV ${ }^{1}$, ARTEM S. SHANOYAN ${ }^{1}$, \\ ALEXANDER Y. KOTS ${ }^{2}$ and VICTORIA A. METELSKAYA ${ }^{1}$ \\ ${ }^{1}$ National Medical Research Center for Preventive Medicine, Ministry of Healthcare \\ of The Russian Federation, Moscow 101990; ${ }^{2}$ Department of Clinical Pharmacology, \\ Sechenov First Moscow State Medical University, Moscow 119992, Russia
}

Received June 12, 2019; Accepted August 22, 2019

DOI: 10.3892/br.2019.1238

\begin{abstract}
Adiponectin, endothelin and nitric oxide (NO) are major regulators of vascular function. An imbalance of vasoactive factors contributes to the onset and progression of atherosclerosis. Various single nucleotide polymorphisms (SNPs) are considered to be risk factors for coronary heart disease. However, the molecular mechanisms of their associations with the components of endothelial dysfunction are poorly understood. In the present study, rs17366743, rs17300539, rs266729, rs182052 and rs2241766 SNPs of the adiponectin (ADIPOQ) gene and rs2070699, rs1800542 and rs1800543 SNPs of the endothelin-1 (EDNI) gene were genotyped in 477 patients with coronary heart disease who were subjected to coronary angiography, in order to determine the presence or absence of coronary atherosclerosis. The serum levels of adiponectin, endothelin and stable metabolites of $\mathrm{NO}$, (nitrate and nitrite NOx), were assayed and their associations with the SNP genotypes and coronary lesions were calculated. The results indicated that rs 17366743 of the $A D I P O Q$ gene and rs2070699 and rs 1800543 of the $E D N 1$ gene were associated with the levels of NOx in women, which in turn was associated with cardiovascular mortality. In men, rs182052 and rs266729 of the $A D I P O Q$ gene were associated with adiponectin levels, whereas rs17366743 of the $A D I P O Q$ gene was associated with endothelin levels. Additionally, these SNPs were indirectly
\end{abstract}

Correspondence to: Dr Nadezhda G. Gumanova, National Medical Research Center for Preventive Medicine, Ministry of Healthcare of The Russian Federation, 10 Petroverigsky Per., Building 3, Moscow 101990, Russia

E-mail: gumanova@mail.ru

Abbreviations: MAF, minor allele frequency; NOx, nitrate and nitrate; OR, odds ratio; ROC, receiver operating characteristic; SNP, single nucleotide polymorphism

Key words: nitric oxide, adiponectin, endothelin, endothelial dysfunction, coronary atherosclerosis, cardiovascular mortality, patients, single nucleotide polymorphism associated with the prevalence of coronary lesions in men. Therefore, the tested SNPs can be considered potential risk factors that lead to imbalance of vasoactive mediators in a gender-specific manner and contribute to the development of clinical manifestations of atherosclerosis.

\section{Introduction}

The onset and development of atherosclerosis involve numerous overlapping modifiable and non-modifiable risk factors. Genome-wide association studies have identified certain genetic elements that predispose to atherosclerosis and include various single nucleotide polymorphisms (SNPs) (1). However, the specific, mechanistic and the clinically relevant associations among genetic factors, mediators of vascular endothelial function and clinical manifestations of the disease are poorly understood.

Adiponectin, endothelin and nitric oxide (NO) are the main vasoactive mediators associated with endothelial dysfunction and atherosclerosis (2). For example, changes in the levels of proinflammatory adipokines can be linked to functional abnormalities of the vascular endothelium and cardiovascular diseases $(3,4)$. Adipokines have been shown to influence the synthesis of other vasoactive mediators in experimental animals $(5,6)$ and in clinical studies $(7,8)$. Adiponectin can suppress atheroma formation (9) and stabilize atherosclerotic plaques due to the stimulation of NO synthesis in endothelial cells (6) and inhibition of endothelial inflammatory processes $(10,11)$. NO produced by the vascular endothelium is a key vasodilator, whereas endothelin is considered a major vasoconstrictor (2). The excessive production of NO is observed in inflammation and can induce oxidative stress and damage the vasculature. Therefore, a balance of adiponectin, endothelin and NO determines the functionally important changes characteristic of atherosclerosis (2).

SNP association studies have indicated that the genes encoding for adiponectin (ADIPOQ) and endothelin-1 (EDNI) are linked to cardiovascular lesions and the clinical manifestations of atherosclerosis. A number of studies have identified certain common allelic elements of the $A D I P O Q$ gene associated with changes in the circulating levels of adiponectin and 
coronary heart disease (4). Additionally, genetic variability of the $A D I P O Q$ gene may determine susceptibility to coronary lesions in patients with type II diabetes (12) and have been identified as risk factors for carotid and coronary atherosclerosis (13). Polymorphisms of the EDNl gene are linked to various disease phenotypes (14). Specifically, certain SNPs may contribute to genetic susceptibility to coronary heart disease (15), neonatal pulmonary hypertension (16) and ischemic stroke (17).

However, the mechanistic connections between these genetic associations and actual symptoms remain to be fully elucidated in a clinically relevant context. Our previous study demonstrated that the balance of circulating levels of adiponectin and endothelin, represented by the adiponectin/endothelin ratio, was associated with coronary stenosis in men (18). Therefore, it was hypothesized that genetic polymorphisms of the $A D I P O Q$ or EDN1 genes may influence the circulating levels of vasoactive mediators and may be associated with the clinical manifestations of atherosclerosis. Stable metabolites of NO, (nitrite and nitrate NOx), are of particular relevance as recent studies indicate that circulating NOx levels are linked to cardiovascular mortality $(19,20)$.

The aim of the present study was to genotype multiple SNPs of the $A D I P O Q$ and $E D N 1$ genes, determine their associations with circulating levels of endothelin, adiponectin and stable metabolites of NO, and investigate the relationships between these parameters and clinical symptoms of atherosclerosis in a group of patients with coronary heart disease.

\section{Patients and methods}

Patients. The present study included 447 male and female patients aged 18-80 years old who were admitted to the National Medical Research Center for Preventive Medicine, Ministry of Healthcare of The Russian Federation (Moscow, Russia) in 2011. The patients were suspected to have coronary artery disease and were subjected to coronary transfemoral angiography by the Judkins method (GE Innova 4100IQ system, GE Healthcare Life Sciences) with subsequent transluminal balloon coronary angioplasty and stenting, as required. Typical indications for angiography included a positive exercise test, positive stress echocardiography, arrhythmia, clear symptoms of advanced angina pectoris, pathological changes on electrocardiogram and physical inability to perform exercise or stress tests, or a high Duke score.

The present study was compliant with the good clinical practice standards and principles of the Declaration of Helsinki. All participants signed informed consent prior to enrolment. The study protocol was approved by the Ethics Committee of the National Medical Research Center for Preventive Medicine, Ministry of Healthcare of The Russian Federation.

The following exclusion criteria were applied: Acute clinical manifestation of atherosclerosis within 6 months of admission; any acute inflammatory disease; chronic kidney failure stage III and above with a glomerular filtration rate $<60 \mathrm{ml} / \mathrm{min} / 1.73 \mathrm{~m}^{2}$; decompensated diabetes mellitus type I or type II with glycated hemoglobin levels $>7.5 \%$; left ventricular ejection fraction $<40 \%$; any oncological disease; any hematological disease, including altered platelet count and blood coagulation; immune and autoimmune diseases.

Details of the clinical assessment and routine biochemical assays performed were described in our previous publication 18).

Biochemical tests. Blood was sampled from the cubital vein after $12 \mathrm{~h}$ of fasting. Serum was aliquoted and stored at $-26^{\circ} \mathrm{C}$ until subsequent assay. Adiponectin was determined by ELISA using kits from BioVendor. Endothelin-1 was measured using an ELISA kit from Affymetrix; Thermo Fisher Scientific, Inc. The linear range of the assay was between 0.5 and $10 \mathrm{fmol} / \mathrm{ml}$. The concentrations of NOx were assayed in the serum deproteinized by filtration through Spin-X UF-5000 molecular weight cut-off concentrators (Corning, Inc.) as described previously (21). Nitrate was reduced to nitrite with $8 \mathrm{mg} / \mathrm{ml}$ vanadium (III) chloride in $1 \mathrm{M} \mathrm{HCl}$ (Sigma; Merck KGaA) and NOx levels were measured via the Griess reaction as described previously (22) with modifications (23).

Extraction of genomic DNA and SNP selection. Genomic DNA was extracted from the whole blood samples using a QIAamp DNA Blood Mini kit (Qiagen $\mathrm{GmbH}$ ) and stored at $-20^{\circ} \mathrm{C}$ until analysis. DNA concentration was determined using a NanoPhotometer (Implen) and adjusted to 5-15 ng/ $\mu \mathrm{l}$.

SNPs of the $A D I P O Q$ and EDN1 genes and the corresponding primers were selected using the ExAC database (http://exac.broadinstitute.org/) to include SNPs significantly associated with circulating levels of adiponectin (rs17300539, rs182052, rs266729, rs2241766 and rs17366743 of the ADIPOQ gene and rs2070699, rs1800542 and rs1800543 of the EDN1 gene) provided that their minor allele frequency (MAF) is $>1 \%$ in the European population.

Genotyping. Genotypes were assayed by real-time PCR using TaqMan reagents from Sintol in a 7500 RT-PCR system (Applied Biosystems, Thermo Fisher Scientific, Inc.). The primers, probes and labels are listed in Table I. Thermal cycling comprised incubation at $63^{\circ} \mathrm{C}$ for $1 \mathrm{~min}$ and at $95^{\circ} \mathrm{C}$ for $3 \mathrm{~min}$ followed by 40 cycles at $95^{\circ} \mathrm{C}$ for $15 \mathrm{sec}$ and $63^{\circ} \mathrm{C}$ for $40 \mathrm{sec}$. Randomly selected samples (10\% or at least three per each genotype) were validated by Sanger sequencing (Evrogen) following 1.5\% agarose gel electrophoresis and subsequent extraction of the PCR products with ExoSAP-IT reagent (Applied Biosystems; Thermo Fisher Scientific, Inc.). The sizes of the PCR products were determined using the Bioanalyzer 2100 system (Agilent Technologies, Inc.).

Statistical analysis. Hardy-Weinberg equilibrium was verified for genotype frequencies using the $\chi^{2}$ test (24). Statistical analysis was performed using SPSS 23 (IBM Corp.). Genotype associations with continuous variables were determined using the Mann-Whitney U test or by Kruskal-Wallis two-tailed non-parametric analysis of variance and specific differences were validated by Dunn's pairwise test. Receiver operating curve (ROC) analysis was used to determine the cut-off values. The association with coronary stenosis was determined by calculating the odds ratio (OR), evaluated using Fisher's exact test with 95\% confidence intervals (CI). The normality of distribution was tested using the Kolmogorov-Smirnov test. $\mathrm{P}<0.05$ was considered to indicate a statistically significant difference. 
Table I. Oligonucleotide primers and probes for eight SNPs of the ADIPOQ and EDN1 genes.

\begin{tabular}{|c|c|c|c|c|}
\hline SNP & Direction & Sequence $\left(5^{\prime}-3^{\prime}\right)$ & Probe & Length (bp) \\
\hline \multirow[t]{2}{*}{ rs17366743 } & $\mathrm{F}$ & GGCAGGAAAGGAGAACC & $\begin{array}{l}\text { (FAM)-AGCGGTATACATAGGCACC- } \\
\text { (RTQ1) }\end{array}$ & 180 \\
\hline & $\mathrm{R}$ & GTACAGCCCAGGAATGTTGC & $\begin{array}{l}\text { (R6G)-CTATGTACACCGCTCAGC- } \\
\text { (BHQ2) }\end{array}$ & \\
\hline \multirow[t]{2}{*}{ rs17300539 } & $\mathrm{F}$ & TTGAAGTTGGTGCTGGCATC & $\begin{array}{l}\text { (FAM)-CAGGATCTGAGCCGGTTC- } \\
\text { (RTQ1) }\end{array}$ & 193 \\
\hline & $\mathrm{R}$ & GGAAGCTGCCACCCACTTA & $\begin{array}{l}\text { (R6G)-CAAGAACCAGCTCAG } \\
\text { ATCC-(BHQ2) }\end{array}$ & \\
\hline \multirow[t]{2}{*}{ rs266729 } & $\mathrm{F}$ & GTTGGTGCTGGCATC & $\begin{array}{l}\text { (FAM)-CAGATCCTGCCCTTCAAA- } \\
\text { (RTQ1) }\end{array}$ & 127 \\
\hline & $\mathrm{R}$ & CCTTGGACTTTCTTGGCACG & $\begin{array}{l}\text { (R6G)-TGCGCTTCAAAAACAAA } \\
\text { ACAT-(BHQ2) }\end{array}$ & \\
\hline \multirow[t]{2}{*}{ rs182052 } & $\mathrm{F}$ & CCTCCGTTCTCCCAC & $\begin{array}{l}\text { (FAM)-CCATTCTGAATTTTGCCCAGT- } \\
\text { (RTQ1) }\end{array}$ & 145 \\
\hline & $\mathrm{R}$ & ACССТTCCACCTTACTGACC & $\begin{array}{l}\text { (R6G)-CCATTCTGAATTTTACCCAGT } \\
\text { TCG-(BHQ2) }\end{array}$ & \\
\hline rs2241766 & $\mathrm{F}$ & $\begin{array}{l}\text { GGATTCCAGGGCTCAGGATG } \\
\text { GCCATCCAACCTGTGCAG }\end{array}$ & $\begin{array}{l}\text { (FAM)-TCTGCCCGGTCATGA-(RTQ1) } \\
\text { (R6G)-TCCTGGTCATGCCCGG-(BHQ2) }\end{array}$ & 139 \\
\hline \multicolumn{5}{|l|}{$\mathrm{B}, E D N 1$} \\
\hline SNP & Direction & Sequence $\left(5^{\prime}-3^{\prime}\right)$ & Probe & Length (bp) \\
\hline \multirow[t]{2}{*}{ rs2070699 } & $\mathrm{F}$ & CTGGACATCATTTGGGTC & $\begin{array}{l}\text { (FAM)-TGTAACCCTAGTCATTCATT } \\
\text { AGCG-(RTQ1) }\end{array}$ & 145 \\
\hline & $\mathrm{R}$ & $\begin{array}{l}\text { TGGATGGTGTTAGAAGGA } \\
\text { CTACC }\end{array}$ & $\begin{array}{l}\text { (R6G)-TTGTAACCCTATTCATTCATT } \\
\text { AGCG-(BHQ2) }\end{array}$ & \\
\hline rs 1800542 & $\begin{array}{l}\mathrm{F} \\
\mathrm{R}\end{array}$ & $\begin{array}{l}\text { GCTAGCTCTGACTCTACTGT } \\
\text { GGACTGGGAGTGGGTTTCTC }\end{array}$ & $\begin{array}{l}\text { (FAM)-CATGTCTCTCGGCGTT-(RTQ1) } \\
\text { (R6G)-CTCTCGACGTTTGAGGA } \\
\text { GAC-(BHQ2) }\end{array}$ & 148 \\
\hline \multirow[t]{2}{*}{ rs 1800543} & $\mathrm{~F}$ & GTGATGAGCTCCTTGTGTGC & $\begin{array}{l}\text { (FAM)-TAGTGTAATTAATAGTCTTT } \\
\text { AAAAT-(RTQ1) }\end{array}$ & 182 \\
\hline & $\mathrm{R}$ & GGTCTGTTGCCTTTG & $\begin{array}{l}\text { (R6G)-TATATTAGTGTGATTAATAG } \\
\text { TCTT-(BHQ2) }\end{array}$ & \\
\hline
\end{tabular}

SNP, single-nucleotide polymorphism; $A D I P O Q$, adiponectin; EDN1, endothelin-1; F, forward; R, reverse; BHQ2, black hole quencher-2; FAM, 6-carboxyfluorescein; R6G, rhodamine 6G; RTQ1, real-time quencher-1.

\section{Results}

A total of 447 patients were subjected to coronary angiography, including 315 men and 132 women; 51 patients did not have coronary lesions. The general characteristics and biochemical test results are listed in Table II. A total of 140 patients were randomly selected for follow up for 4 years, with a cardiovascular mortality rate of $9.2 \%(\mathrm{~N}=13)$.

All participants were genotyped as described above using the primers and probes listed in Table I to assign the alleles of rs17366743, rs17300539, rs266729, rs182052 and rs2241766 SNPs of the $A D I P O Q$ gene and rs2070699, rs1800542 and rs1800543 SNPs of the ENDl gene. Details comprising a brief description, localization, expected European MAF (https://www.ensembl.org/index.html) according to Ensembl release 95, and actual MAF observed in the study with the corresponding pairwise linkage disequilibrium coefficients are listed in Table III. The results indicated that rs266729 and rs182052 may be linked, whereas the remainder of the SNPs appeared to be essentially independent from each other. All genotypes were validated using Sanger sequencing. The allele and genotype frequencies followed the expected values of the Hardy-Weinberg equilibrium in all SNPs $(\mathrm{P}>0.05)$, with the exception of $\mathrm{rs} 266729(\mathrm{P}=0.001)$. The observed MAF for the SNPs of the $A D I P O Q$ gene were within the range of the European population MAF (Table III). 
Table II. General characteristics and biochemical parameters of the patients.

\begin{tabular}{|c|c|c|c|}
\hline Parameters & All $(n=447)$ & $\operatorname{Men}(n=315)$ & Women $(n=132)$ \\
\hline \multicolumn{4}{|l|}{ General, median $(25-75 \%)$} \\
\hline Age (years) & $61(55-69)$ & $60(54-65)^{\mathrm{a}}$ & $65(60-71)$ \\
\hline Weight (kg) & $84.5(75.0-94.0)$ & $86.0(78.0-95.0)^{\mathrm{a}}$ & $78.0(69.0-90.0)$ \\
\hline Body mass index $\left(\mathrm{kg} / \mathrm{m}^{2}\right)$ & $28.7(25.2-32.7)$ & $28.4(26.0-31.5)^{\mathrm{a}}$ & $30.1(26.7-35.1)$ \\
\hline Systolic blood pressure (mmHg) & $130(120-140)$ & $130(120-140)$ & $130(120-140)$ \\
\hline Diastolic blood pressure (mmHg) & $80(76-85)$ & $80(76-85)$ & $80(77-83)$ \\
\hline Heart rate (bpm) & $68(64-74)$ & $68(64-72)^{\mathrm{a}}$ & $70(64-76)$ \\
\hline \multicolumn{4}{|l|}{ Serum biochemistry (mean \pm SD) } \\
\hline Total cholesterol (mmol/l) & $4.98 \pm 1.27$ & $4.86 \pm 1.23^{\mathrm{a}}$ & $5.26 \pm 1.34$ \\
\hline LDL cholesterol (mmol/l) & $3.15 \pm 1.15$ & $3.06 \pm 1.09^{\mathrm{a}}$ & $3.36 \pm 1.28$ \\
\hline HDL cholesterol (mmol/l) & $1.00 \pm 0.26$ & $0.96 \pm 0.25^{\mathrm{a}}$ & $1.10 \pm 0.26$ \\
\hline Triglycerides (mmol/l) & $1.86 \pm 1.28$ & $1.89 \pm 1.25^{\mathrm{a}}$ & $1.80 \pm 1.33$ \\
\hline Adiponectin $(\mu \mathrm{g} / \mathrm{ml})$ & $9.73 \pm 6.57$ & $8.96 \pm 5.90^{\mathrm{a}}$ & $11.56 \pm 7.66$ \\
\hline Endothelin (fmol/ml) & $2.73 \pm 3.46$ & $2.64 \pm 3.35^{\mathrm{a}}$ & $2.93 \pm 3.73$ \\
\hline NOx $(\mu \mathrm{M})$ & $31.29 \pm 20.09$ & $32.66 \pm 19.60^{\mathrm{a}}$ & $27.79 \pm 20.97$ \\
\hline
\end{tabular}

${ }^{\text {a }}<0.05$ vs. women. NOx, nitrate and nitrite; LDL, low-density lipoproteins; HDL, high-density lipoproteins.

Table III. Characteristics of the genotyped SNPs of the ADIPOQ and EDN1 genes.

\begin{tabular}{|c|c|c|c|c|c|c|c|}
\hline \multicolumn{8}{|c|}{$\mathrm{A}, A D I P O Q$} \\
\hline No. & SNP & $\begin{array}{c}\text { Location } \\
\text { (GRCh38.p12) }\end{array}$ & Relation & $\begin{array}{l}\text { Major/minor } \\
\text { allele }\end{array}$ & $\begin{array}{l}\text { MAF } \\
\text { EUR }\end{array}$ & $\begin{array}{l}\text { Observed } \\
\text { MAF }\end{array}$ & $\begin{array}{c}\text { Pairwise } \mathrm{r}^{2} \text { of } \\
\text { linkage disequilibrium }\end{array}$ \\
\hline 1 & rs 17366743 & $3: 186854300$ & $\begin{array}{l}\text { Exon } 3 \text { coding } \\
\text { non-synonymous }\end{array}$ & $\mathrm{T} / \mathrm{C}$ & 0.04 & 0.02 & $0.04^{(1-3)} ; 0.05^{(1-4)} ; 0.03^{(1-5)}$ \\
\hline 2 & rs 17300539 & $3: 186841671$ & Promoter & $\mathrm{G} / \mathrm{A}$ & 0.07 & 0.07 & $0.02^{(2-3)} ; 0.04^{(2-4)}$ \\
\hline 3 & rs266729 & $3: 186841685$ & Promoter & $\mathrm{C} / \mathrm{G}$ & 0.28 & 0.29 & $0.64^{(3-4) \mathrm{b}} ; 0.02^{(3-5)}$ \\
\hline 4 & rs182052 & $3: 186842993$ & Intron & $\mathrm{G} / \mathrm{A}$ & 0.39 & 0.38 & $0.04^{(4-5)}$ \\
\hline 5 & rs2241766 & $3: 186853103$ & $\begin{array}{l}\text { Exon } 2 \text { coding } \\
\text { non-synonymous }\end{array}$ & $\mathrm{T} / \mathrm{G}$ & 0.13 & 0.06 & \\
\hline
\end{tabular}

\section{$\mathrm{B}$, EDN1}

\begin{tabular}{llllllll}
\hline No. & SNP & $\begin{array}{c}\text { Location } \\
\text { (GRCh38.p12) }\end{array}$ & $\begin{array}{c}\text { Relation } \\
\text { to gene }\end{array}$ & $\begin{array}{c}\text { Major/minor } \\
\text { allele }\end{array}$ & $\begin{array}{c}\text { MAF } \\
\text { EUR }\end{array}$ & $\begin{array}{c}\text { Observed } \\
\text { MAF }\end{array}$ & $\begin{array}{c}\text { Pairwise }{ }^{2} \text { of } \\
\text { linkage disequilibrium }\end{array}$ \\
\hline 1 & rs2070699 & $6: 12292539$ & Intron & G/T & 0.47 & 0.5 & $0.04^{(1-2)} ; 0.23^{(1-3)}$ \\
2 & rs1800542 & $6: 12292295$ & Intron & G/A & 0.04 & 0.04 & \\
3 & rs1800543 & $6: 12293904$ & Intron & T/C & 0.22 & 0.21 & \\
\hline
\end{tabular}

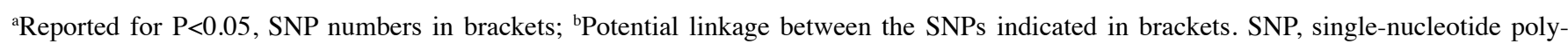
morphism; $A D I P O Q$, adiponectin; EDN1, endothelin-1; GRCh38.p12, Genome Reference Consortium human build 38 patch release 12; MAF, minor allele frequency; MAF EUR, European MAF according to Ensembl release 95.

The majority of the assessed parameters differed between men and women (Table II), therefore, subsequent analysis was performed in men and women separately. The concentrations of NOx, adiponectin and endothelin were compared in men and women with various individual SNP genotypes, as shown in Tables IV and V for the ADIPOQ and EDN1 genes, respectively. Differences in circulating endothelin levels were significant in men with rs17366743 SNP of the ADIPOQ gene, whereas no other SNPs of this gene were associated with the levels of NOx, adiponectin or endothelin. The rs17366743 
Table IV. NOx, adiponectin and enothelin-1 levels in male and female patients with various SNP genotypes of the $A D I P O Q$ gene. A, rs 17366743 SNP

\begin{tabular}{|c|c|c|c|c|c|}
\hline \multirow[b]{2}{*}{ Parameters } & \multirow[b]{2}{*}{ Sex } & \multicolumn{3}{|c|}{ Genotype parameter (count or mean $\pm \mathrm{SD}$ ) } & \multirow[b]{2}{*}{ P-value } \\
\hline & & MM & $\mathrm{Mm}$ & $\mathrm{mm}$ & \\
\hline \multirow[t]{2}{*}{$\mathrm{N}$} & M & 307 & 8 & 0 & \\
\hline & $\mathrm{F}$ & 125 & 6 & 1 & \\
\hline \multirow[t]{2}{*}{ NOx $(\mu \mathrm{M})$} & M & $32.61 \pm 19.78$ & $34.16 \pm 11.21$ & - & 0.39 \\
\hline & $\mathrm{F}$ & $26.66 \pm 19.91$ & $42.95 \pm 31.70$ & 65.47 & 0.10 \\
\hline \multirow[t]{2}{*}{ Adiponectin $(\mu \mathrm{g} / \mathrm{ml})$} & M & $8.96 \pm 5.93$ & $8.98 \pm 4.29$ & - & 0.99 \\
\hline & $\mathrm{F}$ & $11.33 \pm 7.27$ & $15.11 \pm 14.15$ & 19.24 & 0.96 \\
\hline \multirow[t]{2}{*}{ Endothelin (fmol/ml) } & M & $2.68 \pm 4.95$ & $1.11 \pm 0.71$ & - & 0.04 \\
\hline & $\mathrm{F}$ & $2.84 \pm 3.59$ & $5.53 \pm 6.62$ & 1.79 & 0.46 \\
\hline
\end{tabular}

B, rs 17300539 SNP

\begin{tabular}{|c|c|c|c|c|c|}
\hline \multirow[b]{2}{*}{ Parameters } & \multirow[b]{2}{*}{ Sex } & \multicolumn{3}{|c|}{ Genotype parameter (count or mean $\pm \mathrm{SD}$ ) } & \multirow[b]{2}{*}{ P-value } \\
\hline & & MM & $\mathrm{Mm}$ & $\mathrm{mm}$ & \\
\hline \multirow[t]{2}{*}{$\mathrm{N}$} & M & 273 & 40 & 2 & \\
\hline & $\mathrm{F}$ & 112 & 20 & 0 & \\
\hline \multirow[t]{2}{*}{ NOx $(\mu \mathrm{M})$} & M & $32.67 \pm 19.64$ & $33.08 \pm 20.00$ & $32.51 \pm 8.44$ & 0.99 \\
\hline & $\mathrm{F}$ & $26.69 \pm 20.39$ & $35.28 \pm 24.00$ & - & 0.21 \\
\hline \multirow[t]{2}{*}{ Adiponectin $(\mu \mathrm{g} / \mathrm{ml})$} & M & $8.74 \pm 5.69$ & $10.44 \pm 7.13$ & $7.02 \pm 1.07$ & 0.23 \\
\hline & $\mathrm{F}$ & $11.69 \pm 8.05$ & $11.23 \pm 5.25$ & - & 0.63 \\
\hline \multirow[t]{2}{*}{ Endothelin (fmol/ml) } & M & $2.68 \pm 3.33$ & $2.39 \pm 3.55$ & $1.39 \pm 0.16$ & 0.35 \\
\hline & $\mathrm{F}$ & $3.00 \pm 3.73$ & $2.48 \pm 3.71$ & - & 0.48 \\
\hline
\end{tabular}

C, rs266729 SNP

Genotype parameter (count or mean $\pm \mathrm{SD}$ )

\begin{tabular}{|c|c|c|c|c|c|}
\hline \multirow[b]{2}{*}{ Parameters } & \multirow[b]{2}{*}{ Sex } & & \multirow[b]{2}{*}{ P-value } \\
\hline & & MM & $\mathrm{Mm}$ & $\mathrm{mm}$ & \\
\hline \multirow[t]{2}{*}{$\mathrm{N}$} & M & 170 & 112 & 33 & \\
\hline & $\mathrm{F}$ & 70 & 42 & 20 & \\
\hline \multirow[t]{2}{*}{$\mathrm{NOx}(\mu \mathrm{M})$} & M & $31.94 \pm 17.05$ & $31.75 \pm 18.81$ & $39.45 \pm 30.94$ & 0.63 \\
\hline & $\mathrm{F}$ & $26.71 \pm 19.67$ & $27.32 \pm 22.65$ & $32.70 \pm 22.48$ & 0.40 \\
\hline \multirow[t]{2}{*}{ Adiponectin $(\mu \mathrm{g} / \mathrm{ml})$} & M & $9.42 \pm 6.23$ & $8.90 \pm 5.87$ & $6.76 \pm 3.33$ & 0.44 \\
\hline & $\mathrm{F}$ & $11.23 \pm 7.10$ & $12.41 \pm 8.28$ & $10.97 \pm 8.45$ & 0.88 \\
\hline \multirow[t]{2}{*}{ Endothelin (fmol/ml) } & M & $2.76 \pm 3.46$ & $2.47 \pm 3.10$ & $2.58 \pm 3.64$ & 0.80 \\
\hline & $\mathrm{F}$ & $2.98 \pm 3.67$ & $2.93 \pm 4.06$ & $2.76 \pm 3.31$ & 0.99 \\
\hline
\end{tabular}

D, rs182052 SNP

Genotype parameter (count or mean $\pm \mathrm{SD}$ )

\begin{tabular}{|c|c|c|c|c|c|}
\hline \multirow[b]{2}{*}{ Parameters } & \multirow[b]{2}{*}{ Sex } & & \multirow[b]{2}{*}{ P-value } \\
\hline & & $\mathrm{MM}$ & $\mathrm{Mm}$ & $\mathrm{mm}$ & \\
\hline \multirow[t]{2}{*}{$\mathrm{N}$} & M & 125 & 140 & 50 & \\
\hline & $\mathrm{F}$ & 52 & 56 & 24 & \\
\hline \multirow[t]{2}{*}{$\operatorname{NOx}(\mu \mathrm{M})$} & M & $32.05 \pm 18.01$ & $32.05 \pm 18.13$ & $35.85 \pm 26.31$ & 0.86 \\
\hline & $\mathrm{F}$ & $27.56 \pm 21.90$ & $27.23 \pm 20.05$ & $30.31 \pm 21.58$ & 0.87 \\
\hline \multirow[t]{2}{*}{ Adiponectin $(\mu \mathrm{g} / \mathrm{ml})$} & M & $9.83 \pm 6.39$ & $8.64 \pm 5.75$ & $7.68 \pm 4.66$ & 0.30 \\
\hline & $\mathrm{F}$ & $11.86 \pm 7.79$ & $11.51 \pm 7.52$ & $10.94 \pm 7.85$ & 0.56 \\
\hline \multirow[t]{2}{*}{ Endothelin (fmol/ml) } & M & $2.65 \pm 3.36$ & $2.49 \pm 2.99$ & $3.05 \pm 4.21$ & 0.96 \\
\hline & $\mathrm{F}$ & $2.65 \pm 3.45$ & $3.10 \pm 3.93$ & $3.17 \pm 3.95$ & 0.22 \\
\hline
\end{tabular}


Table IV. Continued.

E, rs2241766 SNP

\begin{tabular}{|c|c|c|c|c|c|}
\hline \multirow[b]{2}{*}{ Parameters } & \multirow[b]{2}{*}{ Sex } & \multicolumn{3}{|c|}{ Genotype parameter (count or mean \pm SD) } & \multirow[b]{2}{*}{ P-value } \\
\hline & & MM & $\mathrm{Mm}$ & $\mathrm{mm}$ & \\
\hline \multirow[t]{2}{*}{$\mathrm{N}$} & $\mathrm{N}$ & 276 & 38 & 1 & \\
\hline & $\mathrm{F}$ & 115 & 16 & 1 & \\
\hline \multirow[t]{2}{*}{$\operatorname{NOx}(\mu \mathrm{M})$} & M & $32.78 \pm 20.17$ & $32.43 \pm 15.04$ & 29.33 & 0.49 \\
\hline & $\mathrm{F}$ & $26.41 \pm 19.62$ & $39.74 \pm 28.51$ & 31.86 & 0.13 \\
\hline \multirow[t]{2}{*}{ Adiponectin $(\mu \mathrm{g} / \mathrm{ml})$} & M & $8.86 \pm 5.80$ & $9.81 \pm 6.52$ & 4.16 & 0.31 \\
\hline & $\mathrm{F}$ & $11.38 \pm 7.85$ & $13.24 \pm 6.45$ & 11.06 & 0.51 \\
\hline \multirow[t]{2}{*}{ Endothelin (fmol/ml) } & M & $2.64 \pm 3.35$ & $2.61 \pm 3.43$ & 4.57 & 0.50 \\
\hline & $\mathrm{F}$ & $3.05 \pm 3.93$ & $2.07 \pm 1.76$ & 2.92 & 0.60 \\
\hline
\end{tabular}

$\mathrm{N}$-values of 0-2 were not analyzed. P-values were calculated using Kruskal-Wallis. SNP, single-nucleotide polymorphism; m, male (sex) or minor allele (genotype); f, female; $\mathrm{M}$, major allele; NOx, nitrate and nitrate.

genotype was not associated with the circulating levels of NOx or adiponectin, and there were no associations with levels of endothelin in women (Table IV). In the case of SNPs of the EDN1 gene, the individual rs2070699 and rs1800543 genotypes were associated with circulating levels of NOx in women (Table V).

Significant genotyped allelic associations with circulating levels of NOx, endothelin and adiponectin are listed in Table VI. The data indicate that the rs17366743 SNP of the $A D I P O Q$ gene was associated with an increase (by $73 \%$ ) in the circulating levels of NOx in women and with a decrease (by 59\%) in the levels of endothelin in men. The rs266729 and rs182052 SNPs of the ADIPOQ gene were associated with lower levels of circulating adiponectin in men (by 27 and $9 \%$, respectively), indirectly confirming the results of the pairwise linkage disequilibrium test and suggesting a link between these two SNPs (Table III). In women, the rs2070699 and rs1800543 SNPs of the EDN1 gene were associated with a $43 \%$ decrease and a 35\% increase in the circulating levels of NOx (Table VI). All other possible combinations of associations were tested and determined to be non-significant.

The significant associations were further validated by ROC analysis and by calculating the OR with functional and clinically relevant characteristics of the cohort, including the presence of coronary lesions and 4-year follow up of cardiovascular mortality rate in the randomized fraction of the cohort (Table VII).

The ROC analysis confirmed the association between the $\mathrm{C}$ allele of the rs17366743 SNP of the ADIPOQ gene (CT + CC vs. TT) and elevated circulating levels of NOx. The area under the curve (AUC) was 0.7 (95\% CI 0.46-0.97; $\mathrm{P}=0.07)$ and the NOx cut-off was $34 \mu \mathrm{M}$. At NOx $>34 \mu \mathrm{M}$, the OR of the allele $\mathrm{C}$ genotypes $(\mathrm{CT}+\mathrm{CC}$ ) was 5.7 , indicating that the frequency of the $\mathrm{C}$ allele at these NOx concentrations was almost 6-fold higher than that of the TT allele of the rs17366743 SNP (Table VII). Moreover, the results of the randomized 4-year follow up indicated that elevated levels of NOx $(>34 \mu \mathrm{M})$ were associated with 33-fold higher cardiovascular mortality in women $[\mathrm{N}=4 / 15(21 \%)$ vs. $\mathrm{N}=0 / 27 ; \mathrm{OR}=33$;
95\%CI 1.6-683.8; $\mathrm{P}=0.02$ ] and with 3.4-fold higher cardiovascular mortality in men and women $(\mathrm{N}=9 / 51$ vs. $\mathrm{N}=4 / 77$; $\mathrm{OR}=3.4 ; 95 \% \mathrm{CI} 0.99-11.6 ; \mathrm{P}=0.05)$. Therefore, the $\mathrm{C}$ allele of the rs17366743 SNP of the ADIPOQ gene may be linked to cardiovascular mortality in women with circulating NOx concentrations $>34 \mu \mathrm{M}$. Of note, other SNPs associated with NOx levels, including rs2070699 and rs1800543 of the EDN1 gene, had no associations with coronary lesions or cardiovascular mortality, indicating that the effects of the rs17366743 genotype are unlikely to be mediated exclusively by changes in circulating NOx levels. No other parameters or genotypes had significant associations with mortality; therefore, the association was specific for elevated levels of NOx in women.

In men, elevated levels of NOx were not associated with any of the SNPs. However, higher NOx levels $(>34 \mu \mathrm{M})$ were significantly associated with coronary lesions, as shown in Table VII. Therefore, genetic associations appear to involve NOx levels in a gender-specific manner.

The TT genotype of the rs17366743 SNP of the ADIPOQ gene was associated with elevated levels of endothelin in men compared with the heterozygous TC genotype (Table VII) and this association was confirmed by the ROC analysis (AUC $=0.71 ; 95 \%$ CI $0.5-0.92 ; \mathrm{P}=0.04$ ). The corresponding cut-off endothelin concentration was $0.6 \mathrm{fmol} / \mathrm{ml}$. The frequency of the TC genotype of the rs17366743 SNP was 8.4-fold higher in men with circulating endothelin levels $<0.6 \mathrm{fmol} / \mathrm{ml}$ and the occurrence of coronary artery lesions was 3.4-fold higher than that in men with endothelin concentrations $>0.6 \mathrm{fmol} / \mathrm{ml}$ (Table VII). In women, the ROC analysis of endothelin concentrations at various genotypes indicated a lack of significant associations, whereas ROC analysis comparing the presence of coronary lesions was characterized by AUC 0.7 (95\%CI 0.5-0.7; $\mathrm{P}=0.005)$ with a cut-off at $1.4 \mathrm{fmol} / \mathrm{ml}$. Therefore, elevated concentrations of endothelin $(>1.4 \mathrm{fmol} / \mathrm{ml}$ ) were associated with a 2.5 -fold higher occurrence of coronary artery lesions than that in women with endothelin concentrations $<1.4 \mathrm{fmol} / \mathrm{ml}$.

In men, the allele $\mathrm{C}$ genotypes $(\mathrm{CC}+\mathrm{CG})$ of the rs266729 SNP of the $A D I P O Q$ gene were associated with elevated 
Table V. NOx, endothelin-1 and adiponectin levels in male (m) and female (f) patients with various SNP genotypes of the EDN1 gene.

A, rs2070699SNP

\begin{tabular}{|c|c|c|c|c|c|}
\hline \multirow[b]{2}{*}{ Parameters } & \multirow[b]{2}{*}{ Sex } & \multicolumn{3}{|c|}{ Genotype parameter (count or mean \pm SD) } & \multirow[b]{2}{*}{ P-value } \\
\hline & & MM & $\mathrm{Mm}$ & $\mathrm{mm}$ & \\
\hline \multirow[t]{2}{*}{$\mathrm{N}$} & $\mathrm{M}$ & 80 & 163 & 72 & \\
\hline & F & 32 & 64 & 36 & \\
\hline \multirow[t]{2}{*}{$\mathrm{NOx}, \mu \mathrm{M}$} & M & $32.09 \pm 17.87$ & $31.30 \pm 17.96$ & $36.36 \pm 24.24$ & 0.58 \\
\hline & $\mathrm{F}$ & $40.45 \pm 30.12$ & $23.05 \pm 14.95$ & $23.44 \pm 12.61$ & $<0.01$ \\
\hline \multirow[t]{2}{*}{ Adiponectin, $\mu \mathrm{g} / \mathrm{ml}$} & M & $8.74 \pm 4.60$ & $9.37 \pm 6.65$ & $8.26 \pm 5.33$ & 0.68 \\
\hline & $\mathrm{F}$ & $11.93 \pm 7.66$ & $11.37 \pm 7.25$ & $11.56 \pm 8.54$ & 0.87 \\
\hline \multirow{2}{*}{ Endothelin, fmol/ml } & M & $2.88 \pm 3.53$ & $2.44 \pm 3.20$ & $2.8 \pm 3.49$ & 0.26 \\
\hline & F & $2.21 \pm 2.34$ & $2.97 \pm 3.94$ & $3.48 \pm 4.26$ & 0.27 \\
\hline
\end{tabular}

B, rs1800542 SNP

\begin{tabular}{lccccr}
\hline \multirow{2}{*}{ Parameters } & & \multicolumn{3}{c}{ Genotype parameter (count or mean \pm SD) } \\
\cline { 3 - 5 } & Sex & MM & Mm & mm & P-value \\
\hline $\mathrm{N}$ & $\mathrm{M}$ & 295 & 20 & 0 & \\
$\mathrm{NOx}, \mu \mathrm{M}$ & $\mathrm{F}$ & 116 & 16 & 0 & 0.99 \\
& $\mathrm{M}$ & $32.45 \pm 19.03$ & $35.70 \pm 26.90$ & - & 0.59 \\
Adiponectin, $\mu \mathrm{g} / \mathrm{ml}$ & $\mathrm{F}$ & $28.16 \pm 21.24$ & $25.00 \pm 19.30$ & - & 0.99 \\
& $\mathrm{M}$ & $9.02 \pm 6.00$ & $7.96 \pm 4.04$ & - & 0.81 \\
Endothelin, fmol/ml & $\mathrm{F}$ & $11.75 \pm 7.95$ & $10.19 \pm 5.11$ & - & 0.55 \\
& $\mathrm{M}$ & $2.70 \pm 3.43$ & $1.68 \pm 1.31$ & - & 0.19 \\
\hline
\end{tabular}

C, rs1800543 SNP

\begin{tabular}{|c|c|c|c|c|c|}
\hline \multirow[b]{2}{*}{ Parameters } & \multirow[b]{2}{*}{ Sex } & \multicolumn{3}{|c|}{ Genotype parameter (count or mean \pm SD) } & \multirow[b]{2}{*}{ P-value } \\
\hline & & MM & $\mathrm{Mm}$ & $\mathrm{mm}$ & \\
\hline \multirow[t]{2}{*}{$\mathrm{N}$} & M & 196 & 105 & 14 & \\
\hline & $\mathrm{F}$ & 81 & 47 & 4 & \\
\hline \multirow[t]{2}{*}{$\mathrm{NOx}, \mu \mathrm{M}$} & M & $31.83 \pm 20.45$ & $34.02 \pm 17.40$ & $33.97 \pm 23.33$ & 0.24 \\
\hline & $\mathrm{F}$ & $24.38 \pm 17.74$ & $31.18 \pm 21.84$ & $52.01 \pm 44.01$ & 0.02 \\
\hline \multirow{2}{*}{ Adiponectin, $\mu \mathrm{g} / \mathrm{ml}$} & M & $9.02 \pm 6.13$ & $8.91 \pm 5.65$ & $8.44 \pm 4.54$ & 0.98 \\
\hline & $\mathrm{F}$ & $11.67 \pm 7.11$ & $11.53 \pm 8.92$ & $9.68 \pm 2.48$ & 0.50 \\
\hline \multirow{2}{*}{ Endothelin, fmol/ml } & M & $2.42 \pm 3.08$ & $2.96 \pm 3.79$ & $3.33 \pm 3.44$ & 0.17 \\
\hline & $\mathrm{F}$ & $2.91 \pm 3.87$ & $3.12 \pm 3.62$ & $1.28 \pm 0.86$ & 0.56 \\
\hline
\end{tabular}

N-values of 0-2 were not analyzed. P-values were calculated using Kruskal-Wallis. SNP, single-nucleotide polymorphism; m, male (sex) or minor allele (genotype); f, female; M, major allele; NOx, nitrate and nitrate.

levels of adiponectin and the allele A genotypes (GA + AA) of the rs182052 SNP were associated with lower levels of adiponectin (Table VII). This was confirmed by ROC analysis. In the case of rs266729, the presence of the CC + CG genotype was characterized by AUC $=0.61(95 \% \mathrm{CI} 0.5-0.71 ; \mathrm{P}=0.031)$ and in the case of rs182052, the GG genotypes had AUC $=0.57$
(95\% CI 0.5-0.6; $\mathrm{P}=0.034)$. The corresponding cut-off concentrations of adiponectin were 6.2 and $7.0 \mu \mathrm{g} / \mathrm{ml}$, respectively. In men with adiponectin concentrations $<6.2 \mu \mathrm{g} / \mathrm{ml}$, the frequency of the GG genotype of the rs266729 SNP was 2.02 -fold lower than that in men with adiponectin concentrations $>6.2 \mu \mathrm{g} / \mathrm{ml}$. Similarly, concentrations of adiponectin 
Table VI. Summary of significant differences in NOx, endothelin and adiponectin levels in male and female patients with various SNP genotypes of the $E D N 1$ and $A D I P O Q$ genes.

A, $A D I P O Q$ gene

\begin{tabular}{|c|c|c|c|c|c|c|}
\hline SNP & Parameter & Sex & Genotype & $\mathrm{N}$ & Mean \pm SD & P-value \\
\hline \multirow[t]{4}{*}{ rs17366743 } & \multirow[t]{2}{*}{$\mathrm{NOx}, \mu \mathrm{M}$} & \multirow[t]{2}{*}{$\mathrm{F}$} & MM & 125 & $26.66 \pm 19.91$ & \multirow[t]{2}{*}{0.035} \\
\hline & & & $\mathrm{Mm}+\mathrm{mm}$ & 7 & $46.17 \pm 30.16$ & \\
\hline & \multirow[t]{2}{*}{ Endothelin, fmol/ml } & \multirow[t]{2}{*}{$\mathrm{M}$} & $\mathrm{MM}$ & 307 & $2.68 \pm 4.95$ & \multirow[t]{2}{*}{0.04} \\
\hline & & & $\mathrm{Mm}$ & 8 & $1.11 \pm 0.71$ & \\
\hline \multirow[t]{2}{*}{ rs266729 } & \multirow[t]{2}{*}{ Adiponectin, $\mu \mathrm{g} / \mathrm{ml}$} & \multirow[t]{2}{*}{$\mathrm{M}$} & $\mathrm{MM}+\mathrm{Mm}$ & 282 & $9.21 \pm 6.08$ & \multirow[t]{2}{*}{0.03} \\
\hline & & & $\mathrm{mm}$ & 33 & $6.76 \pm 3.33$ & \\
\hline \multirow[t]{2}{*}{ rs 182052} & \multirow[t]{2}{*}{ Adiponectin, $\mu \mathrm{g} / \mathrm{ml}$} & \multirow[t]{2}{*}{ M } & MM & 125 & $9.83 \pm 6.39$ & \multirow[t]{2}{*}{0.03} \\
\hline & & & $\mathrm{Mm}+\mathrm{mm}$ & 190 & $8.98 \pm 5.49$ & \\
\hline
\end{tabular}

$\mathrm{B}$, EDN1 gene

\begin{tabular}{|c|c|c|c|c|c|c|}
\hline SNP & Parameter & Sex & Genotype & $\mathrm{N}$ & Mean \pm SD & P-value \\
\hline \multirow[t]{2}{*}{ rs2070699 } & $\mathrm{NOx}, \mu \mathrm{M}$ & $\mathrm{F}$ & MM & 32 & $40.45 \pm 30.12$ & 0.0008 \\
\hline & & & $\mathrm{Mm}+\mathrm{mm}$ & 100 & $23.17 \pm 14.07$ & \\
\hline \multirow[t]{2}{*}{ rs1800543 } & $\mathrm{NOx}, \mu \mathrm{M}$ & $\mathrm{F}$ & $\mathrm{MM}$ & 81 & $24.38 \pm 17.74$ & 0.01 \\
\hline & & & $\mathrm{Mm}+\mathrm{mm}$ & 51 & $32.92 \pm 24.37$ & \\
\hline
\end{tabular}

Significance was determined using Mann-Whitney U. SNP, single-nucleotide polymorphism; ADIPOQ, adiponectin; EDN1, endothelin-1; m, male (sex) or minor allele (genotype); f, female; M, major allele; NOx, nitrate and nitrate.

Table VII. Sex-dependent associations of serum biomarkers, SNPs of the $A D I P O Q$ and $E D N 1$ genes and coronary lesions

\begin{tabular}{|c|c|c|c|c|c|}
\hline Serum biomarker & Sex & SNP association & Cut-off & Genotype distribution at cut-off & Coronary lesion at cut-off \\
\hline \multirow[t]{3}{*}{$\mathrm{NOx}, \mu \mathrm{M}$} & $\mathrm{F}$ & $\begin{array}{l}\text { rs } 17366743 \\
A D I P O Q\end{array}$ & $>34$ & $\begin{array}{c}(\mathrm{Mm}+\mathrm{mm}) \text { vs. } \mathrm{MM} \\
\text { OR, 5.7; 95\% CI, 1.06-30.6; P=0.04 }\end{array}$ & NS \\
\hline & $\mathrm{F}$ & rs2070699 EDN1 & $>23$ & $\begin{array}{c}\text { MM vs. }(\mathrm{Mm}+\mathrm{mm}) \\
\text { OR, 2.67; } 95 \% \mathrm{CI}, 1.15-6.26 ; \mathrm{P}=0.023\end{array}$ & NS \\
\hline & M & NS & $>34$ & NS & OR, 2.6; 95\% CI, 0.1-7.02; $\mathrm{P}=0.05$ \\
\hline \multirow[t]{2}{*}{$\begin{array}{l}\text { Endothelin, } \\
\mathrm{fmol} / \mathrm{ml}\end{array}$} & M & $\begin{array}{l}\text { rs } 17366743 \\
A D I P O Q\end{array}$ & $<0.6$ & $\begin{array}{c}\text { Mm vs. MM } \\
\text { OR, 8.4: } 95 \% \text { CI, 1.9-36.1; P=0.004 }\end{array}$ & OR, 3.4; 95\% CI, 1.3-8.8; $\mathrm{P}=0.013$ \\
\hline & $\mathrm{F}$ & $\mathrm{NS}$ & $>1.4$ & NS & OR, $2.5 ; 95 \%$ CI, 1.1-5.7; P=0.04 \\
\hline \multirow[t]{3}{*}{$\begin{array}{l}\text { Adiponectin, } \\
\mu \mathrm{g} / \mathrm{ml}\end{array}$} & M & $\begin{array}{l}\mathrm{rs} 266729 \\
A D I P O Q\end{array}$ & $<6.2$ & $\begin{array}{c}\text { mm vs. }(\mathrm{MM}+\mathrm{Mm}) \\
\mathrm{OR}, 2.02 ; 95 \% \mathrm{CI}, 0.9-4.1 ; \mathrm{P}=0.05\end{array}$ & OR, 2.9; 95\% CI, 1.0-8.2; P=0.04 \\
\hline & M & $\begin{array}{l}\mathrm{rs} 182052 \\
A D I P O Q\end{array}$ & $<7$ & $\begin{array}{c}(\mathrm{Mm}+\mathrm{mm}) \mathrm{vs} . \mathrm{MM} \\
\mathrm{OR}, 1.5 ; 95 \% \mathrm{CI}, 0.95-2.36 ; \mathrm{P}=0.05\end{array}$ & OR, 2.9; 95\% CI, 1.0-8.2; $\mathrm{P}=0.04$ \\
\hline & $\mathrm{F}$ & $\mathrm{NS}$ & NS & NS & NS \\
\hline
\end{tabular}

NS, not significant; SNP, single-nucleotide polymorphism; $A D I P O Q$, adiponectin; EDN1, endothelin-1; m, male (sex) or minor allele (genotype); f, female; M, major allele; NOx, nitrate and nitrate; OR, odds ratio; CI, confidence interval.

$<7.0 \mu \mathrm{g} / \mathrm{ml}$ were associated with 1.5 -fold higher frequency of GG + GA genotypes of the rs182052 SNP. Concentrations of adiponectin $<6.2$ or $7.0 \mu \mathrm{g} / \mathrm{ml}$ were associated with a 2.9-fold higher occurrence of coronary lesions. Therefore, the GG genotype of rs266729 and the GA + AA genotypes of rs182052 were associated with lower concentrations of adiponectin and were linked to an elevated occurrence of coronary lesions in men. In women, these genotypes were not associated with adiponectin levels that, in turn, were not associated with the presence of coronary lesions. 


\section{Discussion}

Endothelial dysfunction is one of the main pathways involved in the onset and progression of atherosclerosis (2). Various regulatory and genetic factors contribute to the imbalance of key vasoactive mediators, including $\mathrm{NO}$, endothelin and adiponectin $(2,4,6)$. Changes in the circulating levels of these mediators alter vascular homeostasis and may induce inflammatory processes that ultimately result in pathological lesions in the vascular wall, including plaque formation and rupture (2).

The adiponectin gene, $A D I P O Q$, is localized to the chromosomal region $3 \mathrm{q} 27$, spans $16 \mathrm{~kb}$ and contains three exons (25). Certain SNPs of the $A D I P O Q$ gene are associated with changes in the circulating levels of adiponectin (26). The levels of adiponectin differ between men and women. In the present study, adiponectin concentrations were significantly lower in men than in women (Table II). Levels of adiponectin are known to be associated with cardiovascular risk and may be linked to the variable gender-dependent distribution of adipose tissue $(27,28)$. For example, the fasting levels of adiponectin in women with myocardial infarction are higher than those in men (29). In the present study, the rs182052 and rs266729 SNPs of the $A D I P O Q$ gene were associated with circulating levels of adiponectin in men but not in women (Tables IV and VI). In addition, lower levels of adiponectin $(<7 \mu \mathrm{g} / \mathrm{ml})$ were associated with a 2.9 -fold higher incidence of coronary lesions. These data are in agreement with a previous study on the associations of rs182052 and rs266729 with the levels of adiponectin and coronary heart disease risk in patients with type II diabetes (12). Therefore, the rs182052 and rs266729 SNPs of the $A D I P O Q$ gene may be involved in the decrease in the circulating levels of adiponectin in men and consequent higher incidence of coronary lesions.

The rs17366743 SNP of the ADIPOQ gene was also associated with endothelin levels, which was in turn associated with the incidence of coronary lesions in men but not in women. A higher incidence of coronary lesions was associated with endothelin in women; however, these associations did not involve the SNPs of the ADIPOQ gene tested (Tables VI and VII). In general, endothelin is one of the major contributors to the maintenance of basal vascular tone and vascular remodeling $(30,31)$. Expression of the EDN1 gene is regulated by multiple factors, including shear stress and hypoxia (32). In addition to these general considerations, our previous study demonstrated that the adiponectin-to-endothelin ratio is associated with the incidence of coronary artery disease in men (18), suggesting that the complex interplay between genetic factors and circulating levels of endothelin and adiponectin may determine the incidence of coronary lesions.

NO is another vasoactive mediator that is regulated by adiponectin. The production of NO in vascular endothelial cells can be enhanced by adiponectin (33). The data in the present study indicated that the $\mathrm{C}$ allele genotypes $(\mathrm{TC}+\mathrm{CC})$ of the rs17366743 SNP of the $A D I P O Q$ gene were associated with elevated concentrations of NOx in the serum of female patients. Additionally, levels of NOx $>34 \mu \mathrm{M}$ were associated with a 33-fold increase in cardiovascular mortality in women. In men, elevated levels of NOx were associated with a 2.6-fold higher incidence of coronary lesions without any significant associations with any of the genotypes tested. These results are in general agreement with our previous observations indicating that high levels of NOx are independent short-term risk factors of cardiovascular mortality (20). These studies have been confirmed in our previous study and another long-term study of cardiovascular and total mortality and morbidity $(19,34)$. In general, changes in the expression of adiponectin can reduce oxidative stress and enhance the endothelial production of $\mathrm{NO}$ in an animal model (6), whereas oxidative stress may influence the expression of adiponectin in perivascular adipose tissue (35) thus forming a complex of regulatory feedback pathways. A similar pattern has been observed in the interplay between NO and endothelin (36), including regulation of the expression of endothelin by NO (30). In agreement with these expectations, the present study observed associations of the rs2070699 and rs1800543 genotypes with NOx concentrations in women. However, these genotypes were not associated with coronary lesions or with cardiovascular mortality.

The present study had inherent limitations that may influence its conclusions. First, only a proportion of the cohort was randomly selected for follow up and thus, the mortality data may introduce certain bias toward the conclusions. However, the differences observed in the study are marked and have high level of significance, which may be considered as indirect validation of the results. Second, the limitations of study budget and size resulted in insufficient data on certain homozygous genotypes and thus, the conclusions rely on heterozygote genotyping. This may be rectified in subsequent larger studies aimed at investigating additional factors contributing to the functional manifestations of polymorphisms in the appropriate context.

In conclusion, the interplay between the vasoactive mechanisms of the onset and progression of atherosclerosis involves complex interactions between genetic and regulatory factors, including adiponectin, endothelin and NO. The present study demonstrated that the rs17366743 SNP of the $A D I P O Q$ gene and rs2070699 and rs1800543 SNPs of the EDN1 gene were associated with the levels of NOx in women. The rs 182052 and rs266729 SNPs of the ADIPOQ gene were associated with adiponectin levels in men and the rs17366743 SNP of the $A D I P O Q$ gene was associated with endothelin levels in men. These associations are gender-specific, appear to reflect the clinical manifestations of coronary lesions and can be considered as potential risk factors of cardiovascular outcomes in a clinically relevant context. Understanding the direct mechanistic connections between various risk factors may promote the development of novel therapeutic strategies to achieve personalized favorable outcomes.

\section{Acknowledgements}

Not applicable.

\section{Funding}

This study was supported by the Russian Science Foundation Project (grant no. 18-75-00087).

\section{Availability of data and materials}

The depersonalized datasets of the present study are available from the corresponding author on reasonable request. 


\section{Authors' contributions}

NGG, MVK and VAM conceived and designed the study; NGG, MVK, SAS, AVK, and OPS collected and processed the clinical data and test results; NGG, MVK, ANM and ASS performed statistical analysis; NGG, MVK, AYK and VAM wrote and edited the manuscript. All authors reviewed and approved the final manuscript.

\section{Ethics approval and consent to participate}

This study was compliant with the good clinical practice standards and the principles of the Declaration of Helsinki. All participants signed an informed consent prior to enrolment. The study protocol was approved by the Ethics Committee of the National Medical Research Center for Preventive Medicine, Ministry of Healthcare of The Russian Federation (Moscow, Russia).

\section{Patient consent for publication}

Not applicable.

\section{Competing interests}

The authors declare that they have no competing interests.

\section{References}

1. CARDIoGRAM plus C4D Consortium, Deloukas P, Kanoni S, Willenborg C, Farrall M, Assimes TL, Thompson JR, Ingelsson E, Saleheen D, Erdmann J, et al: Large-scale association analysis identifies new risk loci for coronary artery disease. Nat Genet 45: 25-33, 2013.

2. Vanhoutte PM, Shimokawa H, Feletou M and Tang EH: Endothelial dysfunction and vascular disease-a 30th anniversary update. Acta Physiol Oxf) 219: 22-96, 2017.

3. Kershaw EE and Flier JS: Adipose tissue as an endocrine organ. J Clin Endocrinol Metab 89: 2548-2556, 2004

4. Dastani Z, Johnson T, Kronenberg F, Nelson CP, Assimes TL, März W; CARDIoGRAM Consortium, ADIPOGen Consortium and Richards JB: The shared allelic architecture of adiponectin levels and coronary artery disease. Atherosclerosis 229: 145-148, 2013.

5. Chen C, Jiang J, Lü JM, Chai H, Wang X, Lin PH and Yao Q: Resistin decreases expression of endothelial nitric oxide synthase through oxidative stress in human coronary artery endothelia cells. Am J Physiol Heart Circ Physiol 299: H193-H201, 2010.

6. Wang X, Pu H, Ma C, Jiang T, Wei Q, Zhang C, Duan M, Shou X, Su L, Zhang J and Yang Y: Adiponectin abates atherosclerosis by reducing oxidative stress. Med Sci Monit 20: 1792-1800, 2014.

7. Wärnberg $J$ and Marcos A: Low-grade inflammation and the metabolic syndrome in children and adolescents. Curr Opin Lipidol 19: 11-15, 2008.

8. Klöting $\mathrm{N}$ and Blüher $\mathrm{M}$ : Adipocyte dysfunction, inflammation and metabolic syndrome. Rev Endocr Metab Disord 15: 277-287, 2014.

9. Fisman EZ and Tenenbaum A: Adiponectin: A manifold therapeutic target for metabolic syndrome, diabetes, and coronary disease? Cardiovasc Diabetol 13: 103, 2014.

10. Ouchi N, Kihara S, Arita Y, Okamoto Y, Maeda K, Kuriyama H, Hotta K, Nishida M, Takahashi M, Muraguchi M, et al: Adiponectin, an adipocyte-derived plasma protein, inhibits endothelial NF-kappaB signaling through a cAMP-dependent pathway. Circulation 102: 1296-1301, 2000.

11. Brown JE, Conner AC, Digby JE, Ward KL, Ramanjaneya M, Randeva HS and Dunmore SJ: Regulation of beta-cell viability and gene expression by distinct agonist fragments of adiponectin. Peptides 31: 944-949, 2010.
12. Tong G, Wang N, Leng J, Tong X, Shen Y, Yang J, Ye X, Zhou L and Zhou Y: Common variants in adiponectin gene are associated with coronary artery disease and angiographical severity of coronary atherosclerosis in type 2 diabetes. Cardiovasc Diabetol 12: 67, 2013.

13. Chen X, Yuan Y, Gao Y, Wang Q, Xie F, Xia D, Wei Y and Xie T: Association of variant in the ADIPOQ gene and functional study for its role in atherosclerosis. Oncotarget 8: 86527-86534, 2017.

14. Ahmed M and Rghigh A: Polymorphism in endothelin-1 gene: An overview. Curr Clin Pharmacol 11: 191-210, 2016.

15. Liang LL, Chen L, Zhou MY, Cai MY, Cheng J, Chen Y, You SK, Chen LB, Tang ZB, Yang XL, et al: Genetic susceptibility of five tagSNPs in the endothelin-1 (EDN1) gene to coronary artery disease in a Chinese Han population. Biosci Rep 38: BSR20171320, 2018

16. Mei M, Cheng G, Sun B, Yang L, Wang H, Sun J and Zhou W: EDN1 gene variant is associated with neonatal persistent pulmonary hypertension. Sci Rep 6: 29877, 2016.

17. Zhang L and Sui R: Effect of SNP polymorphisms of EDN1, EDNRA, and EDNRB gene on ischemic stroke. Cell Biochem Biophys 70: 233-239, 2014.

18. Gumanova NG, Gavrilova NE, Chernushevich OI, Kots AY and Metelskaya VA: Ratios of leptin to insulin and adiponectin to endothelin are sex-dependently associated with extent of coronary atherosclerosis. Biomarkers 22: 239-245, 2017.

19. Gumanova NG, Deev AD, Kots AY and Shalnova SA: Elevated levels of serum nitrite and nitrate, NOx, are associated with increased total and cardiovascular mortality in an 8-year follow-up study. Eur J Clin Invest 49: e13061, 2019.

20. Gumanova NG, Deev AD, Zhang W, Kots AY and Shalnova SA: Serum nitrite and nitrate levels, NOx, can predict cardiovascular mortality in the elderly in a 3-year follow-up study. Biofactors 43: 82-89, 2017.

21. Gumanova NG, Klimushina MV and Metel'skaya VA: Optimization of single-step assay for circulating nitrite and nitrate ions (NOx) as risk factors of cardiovascular mortality. Bull Exp Biol Med 165: 284-287, 2018.

22. Miranda KM, Espey MG and Wink DA: A rapid, simple spectrophotometric method for simultaneous detection of nitrate and nitrite. Nitric Oxide 5: 62-71, 2001.

23. Metel'skaia VA and Gumanova NG: Screening as a method for determining the serum level of nitric oxide metabolites. Klin Lab Diagn 6: 15-18, 2005 In Russian).

24. Rodriguez S, Gaunt TR and Day IN: Hardy-Weinberg equilibrium testing of biological ascertainment for Mendelian randomization studies. Am J Epidemiol 169: 505-514, 2009.

25. Mori Y, Otabe S, Dina C, Yasuda K, Populaire C, Lecoeur C, Vatin V, Durand E, Hara K, Okada T, et al: Genome-wide search for type 2 diabetes in Japanese affected sib-pairs confirms susceptibility genes on $3 \mathrm{q}, 15 \mathrm{q}$, and $20 \mathrm{q}$ and identifies two new candidate loci on 7p and 11p. Diabetes 51: 1247-1255, 2002.

26. Hivert MF, Manning AK, McAteer JB, Florez JC, Dupuis J, Fox CS, O'Donnell CJ, Cupples LA and Meigs JB: Common variants in the adiponectin gene $(A D I P O Q)$ associated with plasma adiponectin levels, type 2 diabetes, and diabetes-related quantitative traits: The Framingham Offspring Study. Diabetes 57: 3353-3359, 2008.

27. Pischon T, Girman CJ, Hotamisligil GS, Rifai N, Hu FB and Rimm EB: Plasma adiponectin levels and risk of myocardial infarction in men. JAMA 291: 1730-1737, 2004.

28. Antoniades C, Antonopoulos AS, Tousoulis D and Stefanadis C: Adiponectin: From obesity to cardiovascular disease. Obes Rev 10: 269-279, 2009.

29. Luque-Ramírez M, Martínez-García MÁ, Montes-Nieto R, Fernández-Durán E, Insenser $M$, Alpañés $M$ and Escobar-Morreale HF: Sexual dimorphism in adipose tissue function as evidenced by circulating adipokine concentrations in the fasting state and after an oral glucose challenge. Hum Reprod 28: 1908-1918, 2013.

30. Brunner F, Brás-Silva C, Cerdeira AS and Leite-Moreira AF: Cardiovascular endothelins: Essential regulators of cardiovascular homeostasis. Pharmacol Ther 111: 508-531, 2006.

31. Kedzierski RM and Yanagisawa M: Endothelin system: The double-edged sword in health and disease. Annu Rev Pharmacol Toxicol 41: 851-876, 2001.

32. Maemura K, Kurihara H, Morita T, Oh-hashi Y and Yazaki Y: Production of endothelin-1 in vascular endothelial cells is regulated by factors associated with vascular injury. Gerontology 38 Suppl 1): S29-S35, 1992. 
33. Hattori Y, Suzuki M, Hattori S and Kasai K: Globular adiponectin upregulates nitric oxide production in vascular endothelial cells. Diabetologia 46: 1543-1549, 2003.

34. Maas R, Xanthakis V, Göen T, Müller J, Schwedhelm E, Böger RH and Vasan RS: Plasma nitrate and incidence of cardiovascular disease and all-cause mortality in the community: The Framingham Offspring Study. J Am Heart Assoc 6: e006224, 2017.

35. Margaritis M,Antonopoulos AS, Digby J,Lee R, Reilly S, CoutinhoP, Shirodaria C, Sayeed R, Petrou M, De Silva R, et al: Interactions between vascular wall and perivascular adipose tissue reveal novel roles for adiponectin in the regulation of endothelial nitric oxide synthase function in human vessels.Circulation 127: 2209-2221,2013.
36. Nguyen A, Thorin-Trescases $\mathrm{N}$ and Thorin E: Working under pressure: Coronary arteries and the endothelin system. Am J Physiol Regul Integr Comp Physiol 298: R1188-R1194, 2010.

(c) (1) $($ This work is licensed under a Creative Commons Attribution-NonCommercial-NoDerivatives 4.0 International (CC BY-NC-ND 4.0) License. 